\title{
Analysis of Solar Dryer using Tono Therm M-65 Phase Change Material
}

\author{
M. Boda ${ }^{1}$ and C. Papade ${ }^{2}$ \\ ${ }^{1}$ PG Student, N. K. Orchid College of Engineering and Technology, Solapur, India \\ ${ }^{2}$ Assitant Professor, N. K. Orchid College of Engineering and Technology, Solapur, India \\ \{manoj.boda07@gmail.com\}
}

\begin{abstract}
This paper presents the construction and performance evaluation of a solar dryer. The objective of this work is to study the performance analysis of solar dryer system with and without Tono Therm m-65 PCM. In this heated air from a separate solar collector is passed through a food tray, and the drying cabinet absorbs solar energy directly through glass roof. an indirect type natural and forced convection solar dryer integrated with PCM has been developed and tested its performance for drying food products under the meteorological conditions of Solapur, India. The performance analysis of a solar dryer system with and without PCM is done for drying grapes. The inclusion of PCM increases the drying time after sunset by 3 hours per day. The forced convection with PCM is more efficient, more suitable for reducing drying time, increasing drying rate, and produces high quality dried grapes. The results obtained that temperatures inside dryer and solar collector were much higher than outside air temperature during most hours of the daylight.
\end{abstract}

Keywords: Indirect type solar dryer, Tono Therm m-65, Phase change material, Night drying, Grapes

\section{Introduction}

The food crises in most developed countries are due in part to the inability to preserve food surpluses. Most of the farmers in world are facing problem with reducing the moisture content from crops to prevent spoilage during storage [1]. The situation is worst for farmers in rural areas where there is no access to electricity. Due to poor preservation most of the harvested crops are susceptible to deterioration [9]. To preserve food products for longer periods drying is one of the most efficient methods. Due to drying the bacterial growth in the products is reduces, drying helps for preserving the products for a long time. There are different solar drying methods, direct type, indirect type, and mixed mode type solar drying. Solar energy is one such renewable source of energy available and is encouraged to be used in every country for its sustainability. There are several researchers working on energy conservation and energy efficiency. As per the present market condition, there are few solar dryers which can be used after the sunset. The solar energy can be stored with the help of energy storing material [8] and this stored energy can be use after the sunset.

\section{Literature review}

Amedorme S. K. et. al. [2] designed and constructed indirect forced convention solar crop dyer for drying $2 \mathrm{~kg}$ moringa leaves having initial moisture of $80 \%$ from which $1.556 \mathrm{~kg}$ of water is removed with $0.62 \mathrm{~m} 2 \mathrm{of}$ solar collection area and solar intensity of $320 \mathrm{~W} / \mathrm{m} 2$. Ogheneruona D. E. et. al. [3] designed and fabricated direct type solar dryer to dry $100 \mathrm{~kg}$ tapioca which is having initial moisture of $79 \%$ in 20 hours. They had taken 7.56 $\mathrm{m} 2$ area of solar collector with solar radiation $13 \mathrm{MJ} / \mathrm{m} 2 /$ day. Bolaji B. O. et. al. [4][12] have designed, constructed and tested the solar wind ventilated cabinet dryer. They observed that drying with the solar cabinet dryer showed better results than open air-drying. Gaeta A. A. [5] had designed and analyzed a cylindrical section solar drying system for drying $70 \mathrm{~kg}$ of bean with collector area of $1.21 \mathrm{~m} 2,750 \mathrm{~W} / \mathrm{m}^{2}$ and $2.43 \mathrm{~kg} / \mathrm{hr}$ flow rate of air. He got a maximum value of thermal efficiency $25.64 \%$.

B. Iyer, S. Nalbalwar and R. Pawade (Eds.)

ICCASP/ICMMD-2016. Advances in Intelligent Systems Research.

Vol. 137, Pp. 35-40.

(C) 2017. The authors - Published by Atlantis Press

This is an open access article under the CC BY-NC license (http://creativecommons.org/licens)es/by-nc/4.0/).

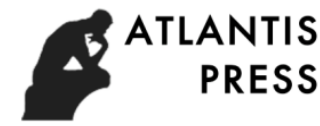


Mohanraj M. and Chandrasekar P. [6] designed; fabricated and investigated an indirect forced convection solar dryer integrated with heat storage material for drying chilli from $72.8 \%$ to the final moisture content $9.2 \%$. They concluded, forced convectionwith inclusion of heat storage material is more suitable for producing high quality dried chilli and increases drying time by 4 hours/day. Forson et al. [7] designed a mixed mode natural convection solar dryer for drying $160 \mathrm{~kg}$ cassava and other crops. $100 \mathrm{~kg}$ of water is required to be removed in 30-36 hours from initial moisture of $67 \%$ with minimum of $42.4 \mathrm{~m} 2$ of solar collector area and solar intensity of $340.4 \mathrm{~W} / \mathrm{m} 2$. Joshua F. [10] design, construction and testing of a simple solar maize dryer. Test results gave temperature above $45 \mathrm{oC}$ in the drying chamber, and the moisture content of $50 \mathrm{~kg}$ of maize reduced to about $12.5 \%$ in three days of 9 hours each day of drying. Cengiz Y. and Cakmak G [11].

\section{Experimental work}

The experimental setup consists of different components such as, solar flat plate collector, phase change material storage tank, drying chamber, trays, blower, reflectors, insulation, etc. The solar dryer consists of solar collector of area $0.5 \mathrm{~m} 2(1 \mathrm{~m} \times 0.5 \mathrm{~m})$. The absorber plate is placed directly behind transparent glass with a layer of air separating. The air to be heated passes between the glass and absorber plate. To pass air into flat plate collector, gap between glass and absorber maintained at $70 \mathrm{~mm}$ [19]. The drying chamber with dimensions 0.5 $\mathrm{m} \times 0.5 \mathrm{~m} \times 0.375 \mathrm{~m}$ and is made up of $4 \mathrm{~mm}$ Bakelite sheet. The solar collector was tilted to an angle $30 \mathrm{o}$ with respect to ground surface and system is faced to south direction.

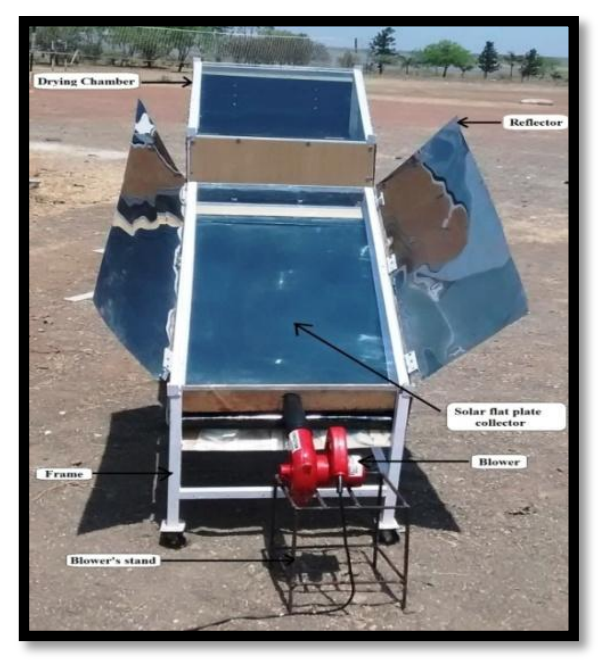

Fig.1. Experimental Set-up

\section{Results and Discussion}

The performance analysis of this system carried out by testing this experimental set-up under different atmospheric conditions (temperature), different air flow rate, and compared these results, this is very necessary for the purpose of evaluation of system parameters. The experiments were carried out with and without phase change materials.

\subsection{Results of natural convection drying with PCM (Case-I)}

Natural convection drying with PCM (Case -I) - In this case the drying is done by without any external agency, i.e. only the naturally flowed air is used. The natural air is having a less velocity and flow rate is varying time to time. In this case PCM is used to store the solar energy; this stored energy can be utilized after the sunset or during no sunshine (clouds).

Initial temperature of food sample $28 \mathrm{oC}$ and initial weight $2000 \mathrm{gm}$., weight of dried sample obtained $550 \mathrm{gm}$; the moisture removed $72.50 \%$ from food sample in 30 hours at a drying rate of $48.33 \mathrm{gm} / \mathrm{hr}$. 
Table 1 Observations of Natural Convection with PCMs

\begin{tabular}{|c|c|c|c|c|c|c|c|}
\hline Time & $\mathrm{T}_{\mathrm{a}}\left({ }^{0} \mathrm{C}\right)$ & $\mathbf{I}_{\mathbf{c}}(\mathbf{L U X})$ & $\mathrm{T}_{\mathrm{in}}\left({ }^{\mathbf{0}} \mathrm{C}\right)$ & $\mathrm{T}_{\text {out }}\left({ }^{\circ} \mathrm{C}\right)$ & $\mathbf{T}_{\mathbf{t}}\left({ }^{0} \mathbf{C}\right)$ & $\mathrm{T}_{\mathrm{m}}\left({ }^{0} \mathrm{C}\right)$ & $\mathrm{T}_{\mathrm{b}}\left({ }^{\circ} \mathrm{C}\right)$ \\
\hline \multicolumn{8}{|c|}{ First day } \\
\hline $10 \mathrm{am}$ & 38 & 100400 & 38 & 38 & 30 & 30 & 30 \\
\hline $11 \mathrm{am}$ & 39 & 101200 & 40 & 43 & 33 & 32 & 32 \\
\hline 12 noon & 40 & 102300 & 42 & 45 & 34 & 33 & 33 \\
\hline $1 \mathrm{pm}$ & 41 & 103000 & 43 & 47 & 35 & 34 & 34 \\
\hline $2 \mathrm{pm}$ & 40 & 102600 & 45 & 49 & 36 & 35 & 35 \\
\hline $3 \mathrm{pm}$ & 39 & 102000 & 42 & 46 & 37 & 36 & 36 \\
\hline $4 \mathrm{pm}$ & 36 & 101200 & 40 & 43 & 38 & 37 & 37 \\
\hline \multicolumn{8}{|c|}{ Drying with PCM } \\
\hline Time & $\mathrm{T}_{\mathrm{a}}\left({ }^{\mathbf{0}} \mathrm{C}\right)$ & $\mathbf{T}_{\mathrm{PCM}}\left({ }^{\mathbf{0}} \mathbf{C}\right)$ & $\mathrm{T}_{\mathrm{in}}\left({ }^{\circ} \mathrm{C}\right)$ & $\mathrm{T}_{\text {out }}\left({ }^{\mathbf{0}} \mathrm{C}\right)$ & $\mathbf{T}_{\mathbf{t}}\left({ }^{\mathbf{0}} \mathbf{C}\right)$ & $\mathbf{T}_{\mathrm{m}}\left({ }^{\mathbf{0}} \mathrm{C}\right)$ & $\mathrm{T}_{\mathrm{b}}\left({ }^{0} \mathrm{C}\right)$ \\
\hline $5 \mathrm{pm}$ & 36 & 78 & 48 & 53 & 39 & 38 & 38 \\
\hline $6 \mathrm{pm}$ & 35 & 76 & 47 & 51 & 40 & 39 & 39 \\
\hline $7 \mathrm{pm}$ & 35 & 73 & 45 & 49 & 41 & 41 & 41 \\
\hline $8 \mathrm{pm}$ & 34 & 71 & 43 & 46 & 42 & 42 & 42 \\
\hline \multicolumn{8}{|c|}{ Second day } \\
\hline $10 \mathrm{am}$ & 38 & 100200 & 38 & 38 & 38 & 38 & 38 \\
\hline $11 \mathrm{am}$ & 40 & 101400 & 40 & 42 & 39 & 39 & 40 \\
\hline 12 noon & 41 & 102600 & 42 & 45 & 40 & 40 & 41 \\
\hline $1 \mathrm{pm}$ & 41 & 102900 & 43 & 47 & 41 & 41 & 42 \\
\hline $2 \mathrm{pm}$ & 40 & 102400 & 44 & 48 & 41 & 41 & 42 \\
\hline $3 \mathrm{pm}$ & 39 & 101800 & 45 & 49 & 40 & 40 & 40 \\
\hline $4 \mathrm{pm}$ & 38 & 101000 & 43 & 46 & 41 & 40 & 40 \\
\hline \multicolumn{8}{|c|}{ Drying with PCM } \\
\hline Time & $\mathrm{T}_{\mathrm{a}}\left({ }^{\mathbf{0}} \mathrm{C}\right)$ & $\mathbf{T}_{\mathrm{PCM}}\left({ }^{0} \mathbf{C}\right)$ & $\mathbf{T}_{\text {in }}\left({ }^{\circ} \mathbf{C}\right)$ & $\mathbf{T}_{\text {out }}\left({ }^{0} \mathrm{C}\right)$ & $\mathbf{T}_{\mathbf{t}}\left({ }^{\mathbf{0}} \mathrm{C}\right)$ & $\mathbf{T}_{\mathrm{m}}\left({ }^{0} \mathrm{C}\right)$ & $\mathrm{T}_{\mathrm{b}}\left({ }^{\mathbf{0}} \mathrm{C}\right)$ \\
\hline $5 \mathrm{pm}$ & 36 & 79 & 50 & 55 & 42 & 41 & 41 \\
\hline $6 \mathrm{pm}$ & 35 & 76 & 49 & 53 & 43 & 42 & 42 \\
\hline $7 \mathrm{pm}$ & 35 & 74 & 47 & 50 & 43 & 43 & 43 \\
\hline $8 \mathrm{pm}$ & 34 & 72 & 43 & 45 & 44 & 44 & 44 \\
\hline \multicolumn{8}{|c|}{ Third day } \\
\hline $10 \mathrm{am}$ & 37 & 100100 & 37 & 37 & 37 & 37 & 37 \\
\hline $11 \mathrm{am}$ & 39 & 101300 & 40 & 43 & 38 & 38 & 38 \\
\hline 12 noon & 40 & 102000 & 42 & 45 & 39 & 39 & 39 \\
\hline $1 \mathrm{pm}$ & 41 & 102700 & 44 & 48 & 39 & 40 & 40 \\
\hline $2 \mathrm{pm}$ & 39 & 101800 & 45 & 49 & 40 & 41 & 41 \\
\hline $3 \mathrm{pm}$ & 38 & 101200 & 43 & 47 & 41 & 40 & 40 \\
\hline $4 \mathrm{pm}$ & 37 & 99800 & 43 & 46 & 42 & 41 & 41 \\
\hline \multicolumn{8}{|c|}{ Drying with PCM } \\
\hline Time & $\mathrm{T}_{\mathrm{a}}\left({ }^{\mathbf{0}} \mathrm{C}\right)$ & $\mathbf{T}_{\mathrm{PCM}}\left({ }^{\mathbf{0}} \mathbf{C}\right)$ & $\mathbf{T}_{\text {in }}\left({ }^{\circ} \mathbf{C}\right)$ & $\mathbf{T}_{\text {out }}\left({ }^{\mathbf{0}} \mathrm{C}\right)$ & $T_{t}\left({ }^{0} \mathbf{C}\right)$ & $\mathbf{T}_{\mathrm{m}}\left({ }^{\mathbf{0}} \mathrm{C}\right)$ & $\mathrm{T}_{\mathrm{b}}\left({ }^{\mathbf{0}} \mathrm{C}\right)$ \\
\hline $5 \mathrm{pm}$ & 36 & 79 & 49 & 5 & 43 & 42 & 42 \\
\hline $6 \mathrm{pm}$ & 35 & 77 & 48 & 53 & 44 & 43 & 43 \\
\hline $7 \mathrm{pm}$ & 35 & 76 & 46 & 50 & 44 & 44 & 44 \\
\hline $8 \mathrm{pm}$ & 34 & 72 & 43 & 45 & 45 & 45 & 45 \\
\hline
\end{tabular}

\subsection{Results of forced convection drying with PCM (Case-II)}

Forced convection dryingwith PCM (Case - II) - In this case the drying is done by using external agency, that is, air blower and energy storing material as PCM for backup purpose. 
Table 2 Observations of Forced Convection with PCMs

\begin{tabular}{|c|c|c|c|c|c|c|c|}
\hline Time & $\mathbf{T}_{\mathrm{a}}\left({ }^{0} \mathrm{C}\right)$ & $\mathbf{I}_{\mathbf{c}}(\mathbf{L U X})$ & $\mathrm{T}_{\mathrm{in}}\left({ }^{\mathbf{0}} \mathrm{C}\right)$ & $\mathrm{T}_{\text {out }}\left({ }^{\circ} \mathrm{C}\right)$ & $\mathbf{T}_{t}\left({ }^{\circ} \mathrm{C}\right)$ & $\mathbf{T}_{\mathrm{m}}\left({ }^{\circ} \mathrm{C}\right)$ & $\mathrm{T}_{\mathrm{b}}\left({ }^{\circ} \mathrm{C}\right)$ \\
\hline \multicolumn{8}{|c|}{ First day } \\
\hline $10 \mathrm{am}$ & 38 & 100500 & 38 & 38 & 29 & 29 & 29 \\
\hline $11 \mathrm{am}$ & 39 & 101200 & 40 & 43 & 32 & 32 & 32 \\
\hline 12 noon & 39 & 102400 & 43 & 47 & 34 & 33 & 34 \\
\hline $1 \mathrm{pm}$ & 40 & 102900 & 48 & 53 & 35 & 34 & 35 \\
\hline $2 \mathrm{pm}$ & 40 & 102600 & 50 & 55 & 38 & 37 & 37 \\
\hline $3 \mathrm{pm}$ & 39 & 101900 & 51 & 56 & 40 & 39 & 39 \\
\hline $4 \mathrm{pm}$ & 37 & 101000 & 49 & 48 & 42 & 40 & 40 \\
\hline \multicolumn{8}{|c|}{ Drying with PCM } \\
\hline Time & $\mathbf{T}_{\mathrm{a}}\left({ }^{0} \mathrm{C}\right)$ & $\mathrm{T}_{\mathrm{PCM}}\left({ }^{0} \mathrm{C}\right)$ & $\mathrm{T}_{\text {in }}\left({ }^{\circ} \mathrm{C}\right)$ & $\mathrm{T}_{\text {out }}\left({ }^{0} \mathrm{C}\right)$ & $\mathbf{T}_{\mathrm{t}}\left({ }^{0} \mathrm{C}\right)$ & $\mathbf{T}_{m}\left({ }^{\circ} \mathrm{C}\right)$ & $\mathbf{T}_{\mathrm{b}}\left({ }^{\circ} \mathrm{C}\right)$ \\
\hline $5 \mathrm{pm}$ & 36 & 79 & 47 & 51 & 43 & 42 & 43 \\
\hline $6 \mathrm{pm}$ & 35 & 76 & 46 & 50 & 44 & 43 & 43 \\
\hline $7 \mathrm{pm}$ & 34 & 72 & 43 & 46 & 43 & 41 & 42 \\
\hline $8 \mathrm{pm}$ & 34 & 69 & 40 & 42 & 41 & 41 & 41 \\
\hline \multicolumn{8}{|c|}{ Second day } \\
\hline $10 \mathrm{am}$ & 38 & 100700 & 38 & 38 & 38 & 38 & 38 \\
\hline $11 \mathrm{am}$ & 39 & 101800 & 40 & 42 & 40 & 40 & 40 \\
\hline 12 noon & 39 & 102700 & 43 & 45 & 42 & 41 & 42 \\
\hline $1 \mathrm{pm}$ & 40 & 103200 & 44 & 48 & 44 & 43 & 44 \\
\hline $2 \mathrm{pm}$ & 38 & 102800 & 45 & 50 & 45 & 45 & 45 \\
\hline $3 \mathrm{pm}$ & 36 & 102200 & 46 & 50 & 46 & 46 & 46 \\
\hline $4 \mathrm{pm}$ & 35 & 101100 & 44 & 49 & 47 & 46 & 47 \\
\hline \multicolumn{8}{|c|}{ Drying with PCM } \\
\hline Time & $\mathbf{T}_{\mathrm{a}}\left({ }^{\circ} \mathrm{C}\right)$ & $\mathrm{T}_{\mathrm{PCM}}\left({ }^{\circ} \mathrm{C}\right)$ & $\mathrm{T}_{\mathrm{in}}\left({ }^{\circ} \mathrm{C}\right)$ & $\mathrm{T}_{\text {out }}\left({ }^{\circ} \mathrm{C}\right)$ & $\mathbf{T}_{t}\left({ }^{\circ} \mathrm{C}\right)$ & $\mathrm{T}_{\mathrm{m}}\left({ }^{\circ} \mathrm{C}\right)$ & $\mathbf{T}_{\mathrm{b}}\left({ }^{\circ} \mathrm{C}\right)$ \\
\hline $5 \mathrm{pm}$ & 35 & 79 & 47 & 51 & 48 & 48 & 48 \\
\hline $6 \mathrm{pm}$ & 34 & 76 & 46 & 50 & 46 & 46 & 46 \\
\hline $7 \mathrm{pm}$ & 34 & 73 & 43 & 46 & 43 & 44 & 43 \\
\hline
\end{tabular}

Initial temperature of food sample $260 \mathrm{C}$ and initial weight $2000 \mathrm{gm}$., weight of dried sample obtained $530 \mathrm{gm}$; the moisture removed $73.50 \%$ from food sample in 21 hours at a drying rate of $77.4 \mathrm{gm} / \mathrm{hr}$.

Natural convection drying without PCM (Case - III) - In this case the drying is done by without any external agency, i.e. only the naturally flowed air is used. The natural air is having a less velocity and flow rate is varying time to time. In this case PCM is not used and drying is done up to sunset only.

Forced convection drying without PCM (Case -IV) - In this case the drying is done by using external agency, that is the air blower up to sunset only because of not used PCM to store solar energy.

The results of case III in this, initial temperature of food sample $260 \mathrm{C}$ and initial weight 2000 gm., weight of dried sample obtained $550 \mathrm{gm}$; the moisture removed $72.50 \%$ from food sample in 45 hours at a drying rate of $32.22 \mathrm{gm} / \mathrm{hr}$.

The results of case IV in this, initial temperature of food sample $26 \mathrm{oC}$ and initial weight 2000 gm., weight of dried sample obtained $540 \mathrm{gm}$; the moisture removed $73.50 \%$ from food sample in 32 hours at a drying rate of $45.63 \mathrm{gm} / \mathrm{hr}$.

The variation of drying time and drying rate with different cases are calculated and plot graph case Vs drying time, and case Vs drying rate is shown in Fig. 2 and Fig. 3 respectively.

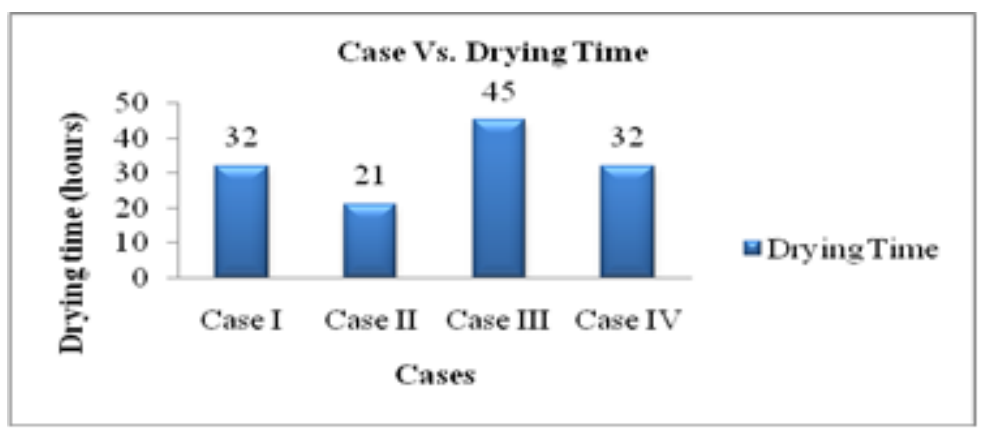

Fig. 2. Case Vs Drying Time 


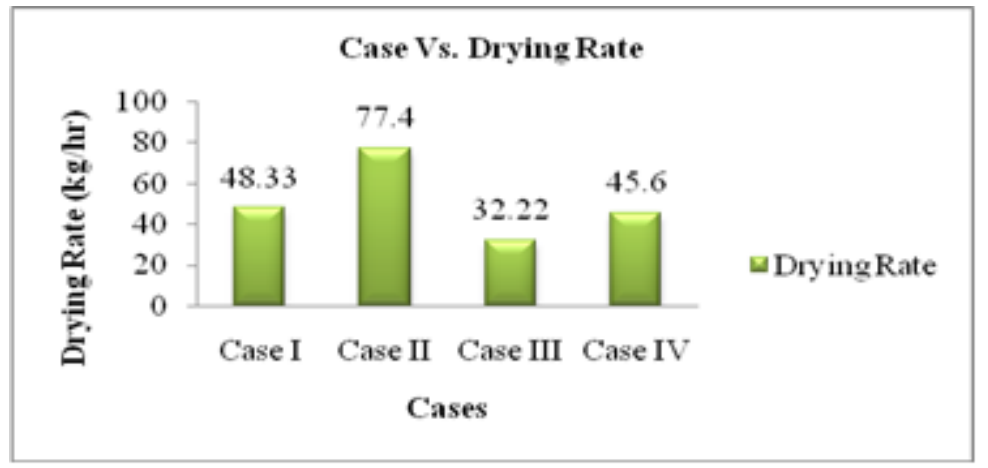

Fig. 3. Case Vs Drying Rate

\section{Conclusions}

The dryer with PCM enables to maintain consistent air temperature inside solar dryer. This dryer system is analyzed in four different conditions like natural convection, natural convection with PCM, forced convection, and forced convection with PCM. The performance of the system is directly based on the atmospheric condition, the intensity of solar radiation, and airflow rate. Thermal efficiency of system was found maximum in forced convection with PCM comparatively in all other three cases. The reduction in drying occurs by increasing air flow rate. The inclusion of PCM increases the drying time by 3 hours per day. The forced convection solar dryer with PCM is more suitable for maintaining high quality dried samples. Although this dryer was used to dry grapes, it can be used to dry other crops like spinach, potato, onion and chilli etc. The capital cost involved in the construction is much lower to that of a mechanical dryer.

\section{Nomenclature}

$\mathrm{T}_{\mathrm{a}}$ : Ambient Temperature

$\mathrm{T}_{\text {in: }}$ Inlet air Temperature

$T_{t}$ : Temperature of top tray

$\mathrm{T}_{\mathrm{b}}$ : Temperature of bottom tray
$\mathrm{I}_{\mathrm{c}}$ : Solar Intensity

$\mathrm{T}_{\text {out: }}$ Outlet air Temperature

$\mathrm{T}_{\mathrm{m}}$ : Temperature of middle tray

$\mathrm{T}_{\mathrm{PCM}}$ : Temperature of PCM

\section{References}

[1] C. Erteken, O. Yaldiz, "Drying of eggplant and selection of a suitable thin layer drying model",Journal of Food Engineering, 63(2004)349-59.

[2] S. Amedorme, J. Apodi, and K. Agbezudor, "Design and Construction of Forced Convection indirect solar dryer for drying moringa leaves”, Scholars Journal of Engineering and Technology,1(2013) 9197.

[3] D. Ogheneruona, and O. Yusuf, "Design and fabrication of a direct natural convection solar dryer for tapioca", Leonardo Electronic Journal of Practices and Technologies, 3(2011) 95-104.

[4] B. Bolaji, M, Olayanju, and T. Falade, "Performance evaluation of a solar wind-ventilated cabinet dryer", The West Indian Journal of Engineering, 33(2011)12-18.

[5] A. Gatea, "Design, construction and performance evaluation of solar maize dryer", Journal of Agricultural Biotechnology and Sustainable Development, vol. 2(2010)39-46.

[6] M. Mohanraj, and P. Chandrasekhar, "Performance of a forced convection solar dryer integrated with gravel as heat storage material for chili drying", Journal of Engineering Science and Technology, $4(2009) 305-314$.

[7] F. Forson, "Designed a mixed-mode natural convection solar crop dryer for drying cassava and other crops", Journal of Renewable Energy,32(2007)2306-2319. 
[8] V. TyagI, A, Sharma, C. Chen, and D. Buddhi, "Review on thermal energy storage with PCM and applications", Renewable and Sustainable Energy Reviews, vol. 13, pp. 318-345,2007.

[9] S. Shalaby, and S. Sebaii, "Solar drying of agricultural products: A review", Renewable and Sustainable Energy Reviews,16(2012)37- 43.

[10] F. Joshua, "Design, Construction and Testing of Simple Solar Maize Dryer", Leonardo Electronic Journal of Practices and Technologies,13(2008)122-130.

[11] Y. Cengiz and G. Çakmak, "Design of a new solar dryer system with swirling flow for drying seeded grape”, International Communications in Heat and Mass Transfer,36(2009)984-990.

[12] B. Bolaji, and A. Olalus, "Performance Evaluation of a Mixed-Mode Solar Dryer", AUJT, 11(2008)225-231.

[13] P. Purohit, A. Kumar, and T. Kandpal,"Solar drying vs. open sun drying: A framework for financial evaluation”, Solar energy, Elsevier,80(2008)1568-1579.

[14] G.N.Tiwari, P.S.Bhatia, A.K.Singih, R.K.Goyal, "Analytical studies of crop drying cum water heating system. Energy Conversion \& Management" 38(1997).

[15] D. R. Jain, K. Jain "Performance evaluation of an inclined multi-pass solar air heater within built thermal storage on deep-bed drying application. Journal of Food Engineering, 65(2004)497-509.

[16] G.N.Tiwari, P.S.Bhatia, A.K.Singih, R. F. Sutar, "Design parameters of a shallow bed solar crop dryer with reflector. Energy Conversion \& Management”35(1994):542-635.

[17] P. M. Chauhan, C. Choudhury, H. P. Garg "Comparative performance of coriander dryer coupled to solar air heater and solar air-heater-cum-rockbed storage. Applied Thermal Engineering, 16(1996):475-86.

[18] D. JaiN "Modeling the system performance of multi-tray crop drying using an inclined multi-pass solar air heater with in-built thermal storage", Journal of Food Engineering, 71(2005)44-54.

[19] D. A. Ajadi., Y. K. Sanusi, A. O. Abiodun, J. O. Bioku, and I. Adeyemo, "Effect of distance between the glass and the absorber on glass and oven temperatures of a locally designed solar cabinet", Web Pub Journal of Scientific Research, 2(2014)5-10.

[20] D. A. Ajadi, Adelabu "Performance of a Locally Designed Solar Dryer:, Zuma J. Pure Appl. Sci, 5(2003) 128-132. 